\title{
Rural Customers' Perception Towards the Fast Moving Consumer Goods: A Hypothesis Test
}

\author{
Ritika Singh, Poonam Singh
}

\begin{abstract}
The Indian FMCG sector is the fourth largest in the Indian economy and has a market size of \$13.1 billion. It includes the production, distribution and marketing of consumer packaged goods, that is those categories of products which are consumed at regular intervals. It has a strong and competitive MNC presence across the entire value chain. The FMCG companies are expected to have a huge growth potential since the percapita consumption of almost all the products in the country is amongst the lowest in the world. Rural market is one of the best opportunities for the FMCG sector. Advertising in rural markets is an upcoming and growing field of marketing. The consumer forms an attitude, which is made by combining choice criteria and brand comprehension. When he becomes certain about his understanding of different brands, he decides whether to purchase or not. If he purchases and the alternative meets his expectation, he may remember it for the next buying decision. It has been found that relatively more continuous or sustained advertising campaign is more suitable for consumer non durables. The buying frequency is high and little decision making is involved and consumers do not actively seek product information. Instead they tend to use whatever information is handy to them.
\end{abstract}

Keywords : FMCG, Advertisement, Rural Market, Consumers, Value chain

\section{INTRODUCTION}

The Indian FMCG sector is the fourth largest sector in the economy and within the FMCG sector; the Indian food processing industry represented 6.3 per cent of GDP which ensures new product launches in the Indian market from the parent's portfolio. Demand for FMCG products is set to boom by almost 60 per cent by 2007 and more than 100 per cent by 2015 . This will be driven by the rise in share of middle class from 67 per cent in 2003 to 88 per cent in 2015 that indicates a latent demand for various product segments. For example, the upper end of very rich and a part of the consuming class indicate a small but rapidly growing segment for branded products. The middle segment, on the other hand, indicates a large market for the mass end products. The BRICs report indicates that India's per capita disposable income, currently at $\$ 556$ per annum, will rise to $\$ 1150$ by 2015 - another FMCG demand

Revised Manuscript Received on July 25, 2019

Dr. Ritika Singh, Assistant Professor (Balaji Institute of Telecom \& Management)

Dr. Poonam Singh, Assistant Professor (Balaji Institute of Telecom \& Management) driver. Spurt in the industrial and services sector growth is also likely to boost the urban consumption demand.

\section{RESEARCH METHODOLOGY}

Research methodology process includes a number of activities to be performed. These are arranged in proper sequence of timing for conducting research. One activity after another is performed to complete the research work. Research methodology includes following steps:

Type of Research

Descriptive Type

\section{Sources of Data}

For the study purpose both primary and secondary data will be used.

Primary data: questionnaire, interview.

Secondary data: journals, magazines, Websites.

\section{Sampling}

Sampling is the process in which a representative part of a population for the purpose of determining parameters or characteristics of the whole population is selected. This is called a sample.The respondents will be selected through simple random sampling process, taking into account the different FMCG products they use daily. FMCG Categories that will be surveyed for the research will be washing soaps, bathing soaps, detergents, tooth paste, hair oil, shampoo, tea, toiletries. (etc) and the survey will be done on the basis of income group, age, educational background.(etc.)

Out of Rajasthan region Udaipur will be selected. City was divided into four zones i.e. Dungarpur (south), Chittaurgarh (east), Rajsamand (north), Banswara (southeast) and from each zone the salesmen, dealers, retailers and customers will be selected from the rural regions. Keeping in view the proper representation of every segment of population and manageable size of the sample, the sample size selected is 250 .

\section{Objective of the study-}

The study of this topic has been undertaken with a number ofobjectives. Following are theobjectives of this study:

1) To evaluate factors exerting influence on consumer decision in rural areas.

2) To provide valuable suggestions for further improvement in FMCG advertising practices in rural areas. 
Hypotheses of the study-

HI) The modes of advertisement and user behaviour are associated

HII) Consumer decision making in rural areas for FMCG is influenced by the magnitude of advertisement.

Individual Product wise

\section{HYPOTHESES TESTING}

Preference for Brand according to various demographic variables

Preference for local and Branded FMCG products according to age-

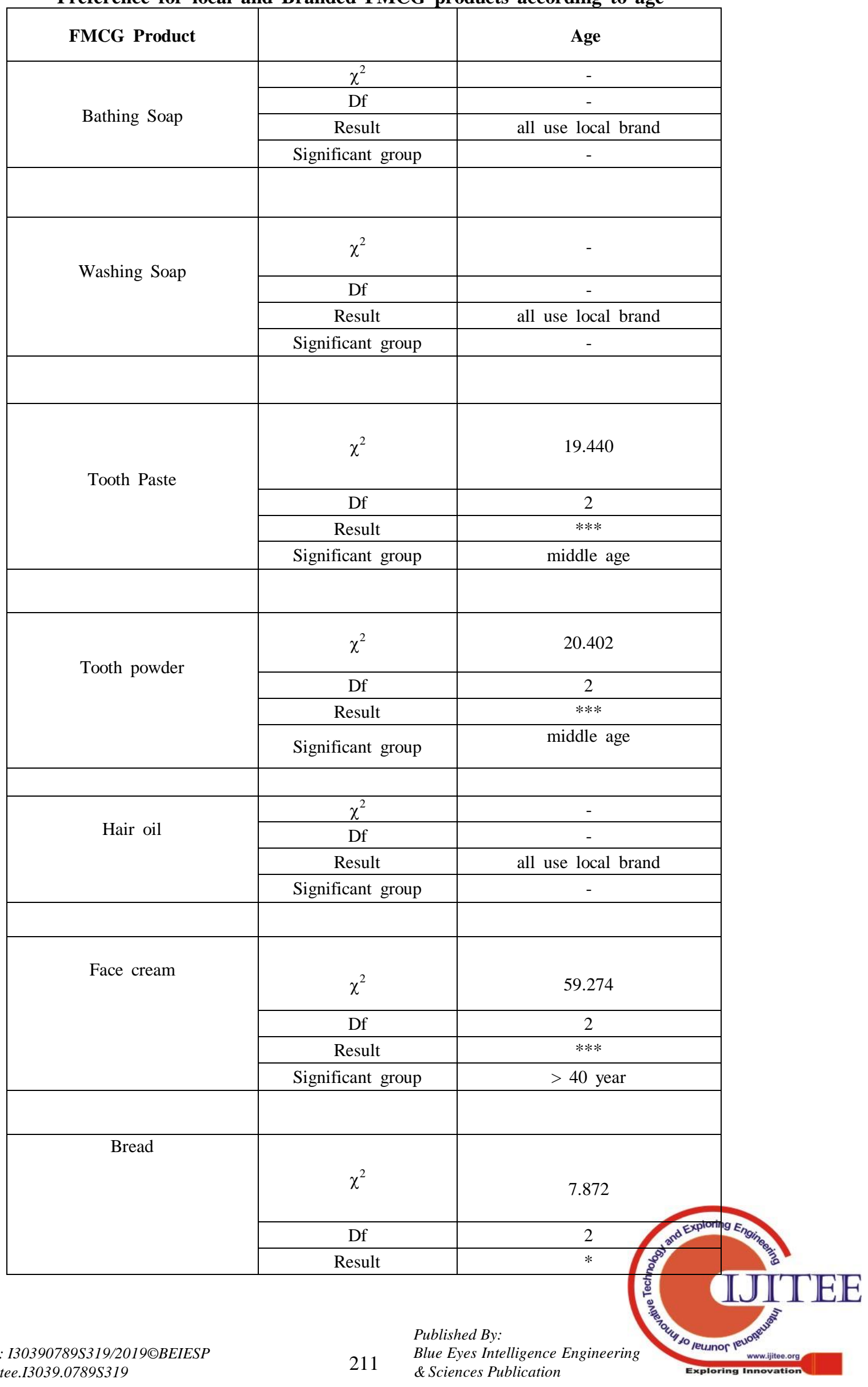


International Journal of Innovative Technology and Exploring Engineering (IJITEE) ISSN: 2278-3075, Volume-8 Issue-9S3, July 2019

\begin{tabular}{|c|c|c|}
\hline FMCG Product & & Age \\
\hline & Significant group & $>40$ year \\
\hline \multirow[t]{4}{*}{ Biscuits } & $\chi^{2}$ & 16.246 \\
\hline & Df & 2 \\
\hline & Result & $* * *$ \\
\hline & Significant group & $>40$ year \\
\hline \multirow[t]{4}{*}{ Soft drink } & $\chi^{2}$ & 29.227 \\
\hline & Df & 2 \\
\hline & Result & $* * *$ \\
\hline & Significant group & $>40$ year \\
\hline \multirow[t]{4}{*}{ Tea } & $\chi^{2}$ & 11.286 \\
\hline & Df & 2 \\
\hline & Result & $* *$ \\
\hline & Significant group & up to $30 \&>40$ years \\
\hline \multirow[t]{4}{*}{ Coffee } & $\chi^{2}$ & 12.132 \\
\hline & Df & 2 \\
\hline & Result & $* *$ \\
\hline & Significant group & $>40$ year \\
\hline \multirow[t]{4}{*}{ Milk } & $\chi^{2}$ & 28.491 \\
\hline & Df & 2 \\
\hline & Result & $* * *$ \\
\hline & Significant group & $>40$ year \\
\hline \multirow{4}{*}{ Talcum Powder } & $\chi^{2}$ & 13.929 \\
\hline & Df & 2 \\
\hline & Result & $* * *$ \\
\hline & Significant group & $31-40 \&>40$ years \\
\hline
\end{tabular}

- $\quad(5 \%$ level of significance)

- $\quad * *$ (1\% level of significance)

- - *** $(0.1 \%$ level of significance

- - df - degree of freedom

- $\quad$ NS-Non Significant
From the above data it can easily be interpreted that in case of washing soap, bathing soap and hair oil, majority is for local brands whereas in case of other fmcg products the accountability somewhere different in 
reference to brand preference. In case of tooth paste and tooth powder the result is significant i.e. middle aged group go for brand preference. In case of face cream, bread, biscuit, coffee, milk ,soft drinks the result is again significant ie. Majority of people who are above 40 years go for brand preference. While for the rest fmcg products like talcum powder and tea, again the result interpreted is significant that lies between 30 and 40 years who has a inclination towards brands.

Preference for local and Branded FMCG products according to gender-

\begin{tabular}{|c|c|c|}
\hline $\begin{array}{l}\text { FMCG } \\
\text { Product }\end{array}$ & & Gender \\
\hline \multirow{4}{*}{$\begin{array}{l}\text { Bathing } \\
\text { Soap }\end{array}$} & $\chi^{2}$ & - \\
\hline & Df & - \\
\hline & Result & $\begin{array}{c}\text { all use local } \\
\text { brand }\end{array}$ \\
\hline & $\begin{array}{c}\text { Significant } \\
\text { group }\end{array}$ & - \\
\hline \multirow{4}{*}{$\begin{array}{l}\text { Washing } \\
\text { Soap }\end{array}$} & $\chi^{2}$ & - \\
\hline & Df & - \\
\hline & Result & $\begin{array}{c}\text { all use local } \\
\text { brand }\end{array}$ \\
\hline & $\begin{array}{c}\begin{array}{c}\text { Significant } \\
\text { group }\end{array} \\
\end{array}$ & - \\
\hline \multirow{4}{*}{$\begin{array}{l}\text { Tooth } \\
\text { Paste }\end{array}$} & $\chi^{2}$ & 2.285 \\
\hline & Df & 1 \\
\hline & Result & NS \\
\hline & $\begin{array}{c}\begin{array}{c}\text { Significant } \\
\text { group }\end{array} \\
\end{array}$ & - \\
\hline \multirow{4}{*}{$\begin{array}{l}\text { Tooth } \\
\text { powder }\end{array}$} & $\chi^{2}$ & 21.029 \\
\hline & Df & 1 \\
\hline & Result & $* * *$ \\
\hline & $\begin{array}{c}\text { Significant } \\
\text { group }\end{array}$ & Male \\
\hline \multirow{4}{*}{ Hair oil } & $\chi^{2}$ & - \\
\hline & Df & - \\
\hline & Result & $\begin{array}{c}\text { all use local } \\
\text { brand }\end{array}$ \\
\hline & $\begin{array}{c}\text { Significant } \\
\text { group }\end{array}$ & - \\
\hline \multirow[t]{4}{*}{$\begin{array}{l}\text { Face } \\
\text { cream }\end{array}$} & $\chi^{2}$ & 1.804 \\
\hline & Df & 1 \\
\hline & Result & NS \\
\hline & $\begin{array}{c}\begin{array}{c}\text { Significant } \\
\text { group }\end{array} \\
\end{array}$ & - \\
\hline
\end{tabular}

\begin{tabular}{|c|c|c|}
\hline \multirow{4}{*}{ Bread } & $\chi^{2}$ & - \\
\hline & Df & - \\
\hline & Result & All \\
\hline & $\begin{array}{c}\text { Significant } \\
\text { group }\end{array}$ & Local \\
\hline \multirow{4}{*}{ Biscuits } & $\chi^{2}$ & 1.251 \\
\hline & Df & 1 \\
\hline & Result & NS \\
\hline & $\begin{array}{c}\text { Significant } \\
\text { group }\end{array}$ & - \\
\hline \multirow{4}{*}{ Soft drink } & $\chi^{2}$ & 1.594 \\
\hline & $\mathrm{Df}$ & 1 \\
\hline & Result & NS \\
\hline & $\begin{array}{c}\text { Significant } \\
\text { group }\end{array}$ & - \\
\hline \multirow{4}{*}{ Tea } & $\chi^{2}$ & 5.135 \\
\hline & Df & 1 \\
\hline & Result & $*$ \\
\hline & $\begin{array}{c}\text { Significant } \\
\text { group }\end{array}$ & Male \\
\hline \multirow{4}{*}{ Coffee } & $\chi^{2}$ & 3.315 \\
\hline & Df & 1 \\
\hline & Result & NS \\
\hline & $\begin{array}{c}\text { Significant } \\
\text { group }\end{array}$ & - \\
\hline \multirow{4}{*}{ Milk } & $\chi^{2}$ & 2.581 \\
\hline & $\mathrm{Df}$ & 1 \\
\hline & Result & NS \\
\hline & $\begin{array}{c}\text { Significant } \\
\text { group }\end{array}$ & - \\
\hline \multirow{5}{*}{$\begin{array}{c}\text { Talcum } \\
\text { Powder }\end{array}$} & $\chi^{2}$ & - \\
\hline & $\mathrm{Df}$ & - \\
\hline & Result & All \\
\hline & $\begin{array}{c}\text { Significant } \\
\text { group }\end{array}$ & $\begin{array}{c}\text { All male use } \\
\text { talcum powder } \\
\text { (branded) no } \\
\text { female }\end{array}$ \\
\hline & & \\
\hline
\end{tabular}

- $(5 \%$ level of significance)

- ** (1\% level of significance)

- *** $(0.1 \%$ level of significance

Published By: 
- df - degree of freedom

- NS-Non Significant

In case of interpreting brand preference for fmcg products according to gender, it can be interpreted from the above data that in case of tea, tooth powder and talcum powder, all male has a higher brand preference in comparison to female. While for the rest of the fmcg products the result got is non significant i.e. Consumers do not have a craving for branded products rather they all go for local brands irrespective of gender.

Preference for Branded and Local FMCG products according to marital status-

\begin{tabular}{|c|c|c|}
\hline $\begin{array}{l}\text { FMCG } \\
\text { Product }\end{array}$ & & $\begin{array}{c}\text { Marital } \\
\text { status }\end{array}$ \\
\hline \multirow{4}{*}{ Bathing Soap } & $\chi^{2}$ & - \\
\hline & $\mathrm{df}$ & - \\
\hline & Result & $\begin{array}{c}\text { all use local } \\
\text { brand }\end{array}$ \\
\hline & $\begin{array}{c}\text { Significant } \\
\text { group }\end{array}$ & - \\
\hline \multirow{4}{*}{ Washing Soap } & $\chi^{2}$ & - \\
\hline & df & - \\
\hline & Result & $\begin{array}{c}\text { all use local } \\
\text { brand } \\
\end{array}$ \\
\hline & $\begin{array}{c}\text { Significant } \\
\text { group }\end{array}$ & - \\
\hline \multirow{4}{*}{ Tooth Paste } & $\chi^{2}$ & 5.167 \\
\hline & $\mathrm{df}$ & 2 \\
\hline & Result & NS \\
\hline & $\begin{array}{c}\text { Significant } \\
\text { group }\end{array}$ & - \\
\hline \multirow[t]{4}{*}{ Tooth powder } & $\chi^{2}$ & 0.179 \\
\hline & $\mathrm{df}$ & 1 \\
\hline & Result & NS \\
\hline & $\begin{array}{c}\text { Significant } \\
\text { group }\end{array}$ & - \\
\hline \multirow{4}{*}{ Hair oil } & $\chi^{2}$ & - \\
\hline & $\mathrm{df}$ & - \\
\hline & Result & $\begin{array}{c}\text { all use local } \\
\text { brand }\end{array}$ \\
\hline & $\begin{array}{c}\text { Significant } \\
\text { group }\end{array}$ & - \\
\hline \multirow{2}{*}{ Face cream } & $\chi^{2}$ & 3.196 \\
\hline & $\mathrm{df}$ & 1 \\
\hline
\end{tabular}

- $(5 \%$ level of significance)

- ** (1\% level of significance)

- *** $(0.1 \%$

level of significance 
- df - degree of freedom

- NS-Non Significant

In case of interpreting brand preference for fmcg products according to marital status, it can be interpreted that in case of washing soap , bathing soap and hair oil , both married as well as unmarried accounts for local brands, and for the rest ie. Talcum powder, milk, coffee, tea, biscuits, bread, face cream, tooth paste and tooth powder, the result is non significant that means both married as well as unmarried use local brands. While in case of soft drinks, married people have a higher edge over unmarried ie they use branded soft drinks.

Preference for Branded and Local FMCG products according to education-

\begin{tabular}{|c|c|c|}
\hline $\begin{array}{l}\text { FMCG } \\
\text { Product }\end{array}$ & & Education \\
\hline \multirow{4}{*}{$\begin{array}{c}\text { Bathing } \\
\text { Soap }\end{array}$} & $\chi^{2}$ & - \\
\hline & Df & - \\
\hline & Result & $\begin{array}{c}\text { all use local } \\
\text { brand }\end{array}$ \\
\hline & $\begin{array}{c}\text { Significant } \\
\text { group }\end{array}$ & - \\
\hline \multirow{4}{*}{$\begin{array}{c}\text { Washing } \\
\text { Soap }\end{array}$} & $\chi^{2}$ & - \\
\hline & Df & - \\
\hline & Result & $\begin{array}{c}\text { all use local } \\
\text { brand }\end{array}$ \\
\hline & $\begin{array}{c}\text { Significant } \\
\text { group }\end{array}$ & - \\
\hline \multirow{4}{*}{ Tooth Paste } & $\chi^{2}$ & 5.802 \\
\hline & Df & 3 \\
\hline & Result & NS \\
\hline & $\begin{array}{c}\text { Significant } \\
\text { group }\end{array}$ & - \\
\hline \multirow{4}{*}{$\begin{array}{l}\text { Tooth } \\
\text { powder }\end{array}$} & $\chi^{2}$ & 24.472 \\
\hline & Df & 3 \\
\hline & Result & $* * *$ \\
\hline & $\begin{array}{c}\text { Significant } \\
\text { group }\end{array}$ & Graduate \\
\hline \multirow[t]{4}{*}{ Hair oil } & $\chi^{2}$ & - \\
\hline & Df & - \\
\hline & Result & $\begin{array}{c}\text { all use local } \\
\text { brand }\end{array}$ \\
\hline & $\begin{array}{c}\text { Significant } \\
\text { group }\end{array}$ & - \\
\hline
\end{tabular}

\begin{tabular}{|c|c|c|}
\hline \multirow[t]{4}{*}{ Face cream } & $\chi^{2}$ & 4.661 \\
\hline & Df & 3 \\
\hline & Result & NS \\
\hline & $\begin{array}{c}\text { Significant } \\
\text { group }\end{array}$ & - \\
\hline \multirow{4}{*}{ Bread } & $\chi^{2}$ & 1.415 \\
\hline & Df & 1 \\
\hline & Result & NS \\
\hline & $\begin{array}{c}\begin{array}{c}\text { Significant } \\
\text { group }\end{array} \\
\end{array}$ & - \\
\hline \multirow{4}{*}{ Biscuits } & $\chi^{2}$ & 2.214 \\
\hline & Df & 3 \\
\hline & Result & NS \\
\hline & $\begin{array}{c}\text { Significant } \\
\text { group }\end{array}$ & - \\
\hline \multirow{4}{*}{ Soft drink } & $\chi^{2}$ & 2.862 \\
\hline & Df & 2 \\
\hline & Result & NS \\
\hline & $\begin{array}{c}\text { Significant } \\
\text { group }\end{array}$ & - \\
\hline \multirow{4}{*}{ Tea } & $\chi^{2}$ & 6.11 \\
\hline & Df & 4 \\
\hline & Result & NS \\
\hline & $\begin{array}{c}\text { Significant } \\
\text { group }\end{array}$ & - \\
\hline \multirow{4}{*}{ Coffee } & $\chi^{2}$ & 3.315 \\
\hline & Df & 1 \\
\hline & Result & NS \\
\hline & $\begin{array}{c}\begin{array}{c}\text { Significant } \\
\text { group }\end{array} \\
\end{array}$ & - \\
\hline \multirow[t]{4}{*}{ Milk } & $\chi^{2}$ & 4.071 \\
\hline & Df & 4 \\
\hline & Result & NS \\
\hline & $\begin{array}{c}\begin{array}{c}\text { Significant } \\
\text { group }\end{array} \\
\end{array}$ & - \\
\hline \multirow{2}{*}{$\begin{array}{l}\text { Talcum } \\
\text { Powder }\end{array}$} & $\chi^{2}$ & 7.564 \\
\hline & Df & \\
\hline
\end{tabular}


- $(5 \%$ level of significance)

- ** (1\% level of significance)

- *** $(0.1 \%$ level of significance

- df - degree of freedom

- NS-Non Significant

In case of interpreting brand preference for fmcg products according to education, it can be interpreted that in case of bathing soap, washing soap and hair oil, both the categories i.e. educated or uneducated use local brands and for the rest i.e. milk, coffee, tea, soft drink, biscuits, bread, face cream, and tooth paste the result is non significant. While in case of tooth powder and talcum powder, the result is significant i.e. graduates and $\mathrm{sec} / \mathrm{sr}$. sec. groups use branded fmcg products respectively.

Preference for Branded and local FMCG products according to occupation-

\begin{tabular}{|c|c|c|}
\hline $\begin{array}{l}\text { FMCG } \\
\text { Product } \\
\end{array}$ & & Occupation \\
\hline \multirow{4}{*}{$\begin{array}{c}\text { Bathing } \\
\text { Soap }\end{array}$} & $\chi^{2}$ & - \\
\hline & Df & - \\
\hline & Result & $\begin{array}{c}\text { all use local } \\
\text { brand }\end{array}$ \\
\hline & $\begin{array}{c}\text { Significant } \\
\text { group }\end{array}$ & - \\
\hline \multirow{4}{*}{$\begin{array}{c}\text { Washing } \\
\text { Soap }\end{array}$} & $\chi^{2}$ & - \\
\hline & Df & - \\
\hline & Result & $\begin{array}{c}\text { all use local } \\
\text { brand }\end{array}$ \\
\hline & $\begin{array}{c}\text { Significant } \\
\text { group }\end{array}$ & - \\
\hline \multirow{4}{*}{ Tooth Paste } & $\chi^{2}$ & 9.159 \\
\hline & df & 3 \\
\hline & Result & $*$ \\
\hline & $\begin{array}{c}\text { Significant } \\
\text { group }\end{array}$ & Private job \\
\hline \multirow{4}{*}{$\begin{array}{l}\text { Tooth } \\
\text { powder }\end{array}$} & $\chi^{2}$ & 45.638 \\
\hline & df & 2 \\
\hline & Result & $* * *$ \\
\hline & $\begin{array}{c}\text { Significant } \\
\text { group }\end{array}$ & Private job \\
\hline & $\chi^{2}$ & - \\
\hline & df & - \\
\hline
\end{tabular}

- $(5 \%$ level of significance) 
- ** $(1 \%$ level of significance)

- *** $(0.1 \%$ level of significance

- df - degree of freedom

- NS-Non Significant

From the above data, it can be interpreted that in case of milk, talcum powder, tea, tooth paste, tooth powder, majority of consumers those are into private jobs use brands. While in the case of coffee, soft drinks, biscuits, bread, face cream, the result is non significant. And for the rest categories, like hair oil, washing soap, bathing soap, all use local brands irrespective of occupation.

Preference for Branded and local FMCG products according to income-

\begin{tabular}{|c|c|c|}
\hline $\begin{array}{l}\text { FMCG } \\
\text { Product }\end{array}$ & & Income \\
\hline \multirow{4}{*}{ Bathing Soap } & $\chi^{2}$ & - \\
\hline & df & - \\
\hline & Result & $\begin{array}{c}\text { all use local } \\
\text { brand }\end{array}$ \\
\hline & $\begin{array}{c}\text { Significant } \\
\text { group }\end{array}$ & - \\
\hline \multirow{4}{*}{ Washing Soap } & $\chi^{2}$ & - \\
\hline & $\mathrm{df}$ & - \\
\hline & Result & $\begin{array}{c}\text { all use local } \\
\text { brand }\end{array}$ \\
\hline & $\begin{array}{c}\text { Significant } \\
\text { group }\end{array}$ & - \\
\hline \multirow{4}{*}{ Tooth Paste } & $\chi^{2}$ & 2.43 \\
\hline & df & 2 \\
\hline & Result & NS \\
\hline & $\begin{array}{c}\text { Significant } \\
\text { group }\end{array}$ & - \\
\hline \multirow{4}{*}{ Tooth powder } & $\chi^{2}$ & 20.3 \\
\hline & df & 1 \\
\hline & Result & $* * *$ \\
\hline & $\begin{array}{c}\text { Significant } \\
\text { group }\end{array}$ & $10000-20000$ \\
\hline \multirow{4}{*}{ Hair oil } & $\chi^{2}$ & - \\
\hline & df & - \\
\hline & Result & $\begin{array}{c}\text { all use local } \\
\text { brand } \\
\end{array}$ \\
\hline & $\begin{array}{c}\text { Significant } \\
\text { group }\end{array}$ & - \\
\hline & $\chi^{2}$ & 1.616 \\
\hline & df & 2 \\
\hline
\end{tabular}


- ** $(1 \%$ level of significance)

- *** $(0.1 \%$ level of significance

- df - degree of freedom

- NS-Non Significant

From the above data, it can be concluded that, consumers of income group up to $10000 /$ month use branded fmcg products like talcum powder, coffee and soft drinks. Other than this, consumers of income group between 10000-20000 / month use branded products like bread and tooth powder. In case of milk, tea, biscuits, face cream and tooth paste, the result is non significant. And for the rest such as bathing soap, washing soap, hair oil, all income groups use local brands.

Modes of advertisement and user behaviour are associated

$\mathbf{R}=$ correlation coefficient

$\mathbf{N}=$ sample size

Association between advertisement and user behaviour

\begin{tabular}{|c|c|c|c|}
\hline $\begin{array}{c}\text { Adv. } \\
\text { Media }\end{array}$ & $\mathbf{R}$ & Result & N \\
\hline Newspaper & 0.369 & $* * *$ & 232 \\
\hline Magazines & 0.495 & $* * *$ & 183 \\
\hline Radio & 0.684 & $* * *$ & 201 \\
\hline Television & 0.835 & $* * *$ & 221 \\
\hline Mobile & 0.772 & $* * *$ & 210 \\
\hline Internet & 0.950 & $* * *$ & 188 \\
\hline
\end{tabular}

Correalation between extent of use of media and its help in making purchase decision regarding FMCG products

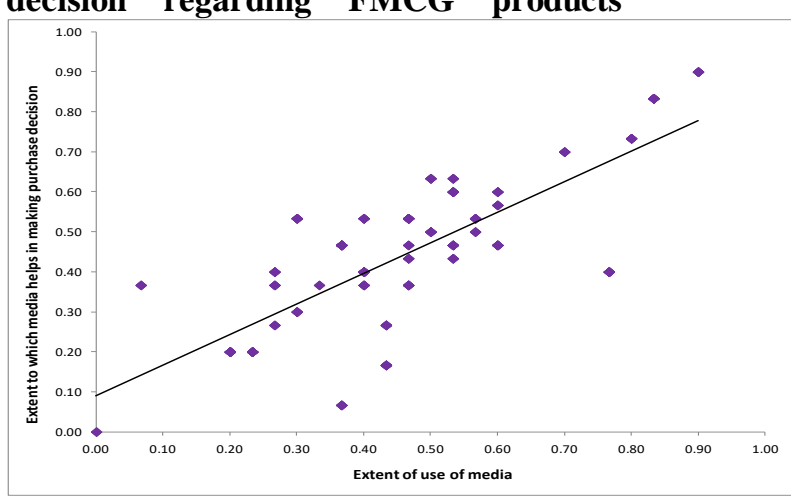

Table shows correlation test results between use of different media and help of that media in making purchase decision about FMCG product. The results show highly significant correlation between extent of use of different media and help of that media in making purchase decision.
For media like Internet, television, mobile and radio a highly significant correlation was found but it was very high for Internet, television, mobile and radio in the decreasing order of value of correlation and low for newspaper and magazine which is obvious because in rural areas people use newspaper and magazines very less as compared to other media like TV, radio etc. It is also observed that they are using internet at high extent because of the availability of internet on smart-phones hence internet in exerting great influence in making purchase decision about FMCG products.

This proves our hypothesis that mode of advertisement and user behavior are associated.

Consumer decision making in rural areas for FMCG is influenced by magnitude of advertisement.

$\mathbf{R}=$ correlation coefficient

$\mathbf{N}=$ sample size

$\mathbf{P}=$ level of significance

\begin{tabular}{|l|c|c|c|}
\hline \multicolumn{1}{|c|}{ FMCG Product } & R & P & N \\
\hline Bathing Soap & 0.449 & $* * *$ & 244 \\
\hline Washing Soap & 0.450 & $* * *$ & 231 \\
\hline Tooth Paste & 0.600 & $* * *$ & 166 \\
\hline Tooth Powder & -0.016 & NS & 83 \\
\hline Hair Oil & 0.297 & $* * *$ & 216 \\
\hline Face cream & 0.499 & $* * *$ & 100 \\
\hline Bread & 0.469 & $* * *$ & 53 \\
\hline Biscuits & 0.519 & $* * *$ & 124 \\
\hline Soft drink & 0.305 & $* * *$ & 74 \\
\hline Tea & 0.726 & $* * *$ & 173 \\
\hline Coffee & 0.670 & $* * *$ & 45 \\
\hline Milk & 0.615 & $* * *$ & 199 \\
\hline Talcum Powder & 0.360 & $*$ & 39 \\
\hline
\end{tabular}

\begin{tabular}{|c|c|c|}
\hline Product Category & R & Result \\
\hline Hygiene & 0.512 & $* * *$ \\
\hline Beauty & 0.773 & $* * *$ \\
\hline Eatable & 0.773 & $* * *$ \\
\hline Drinks & 0.761 & $* * *$ \\
\hline
\end{tabular}

Correlation between influence of media in making purchase decision regarding Hygiene Products 

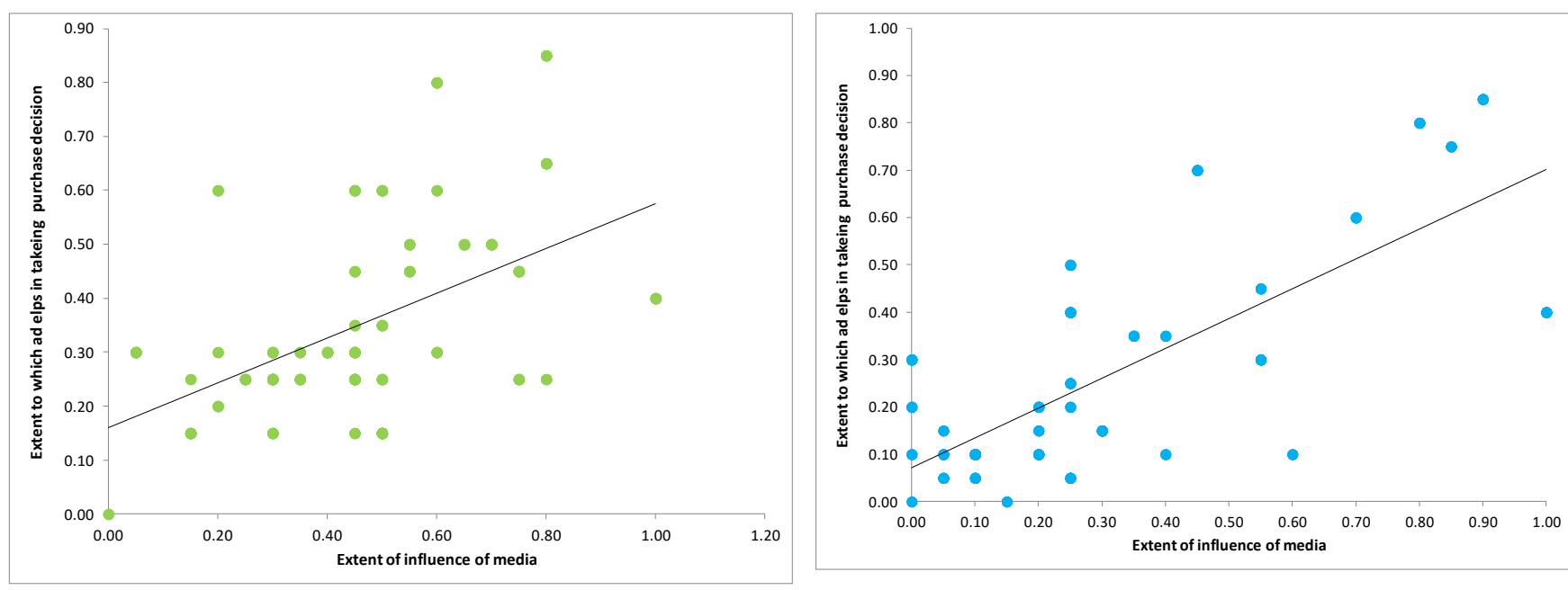

Correlation between influence of media in making purchase decision regarding Beauty Products

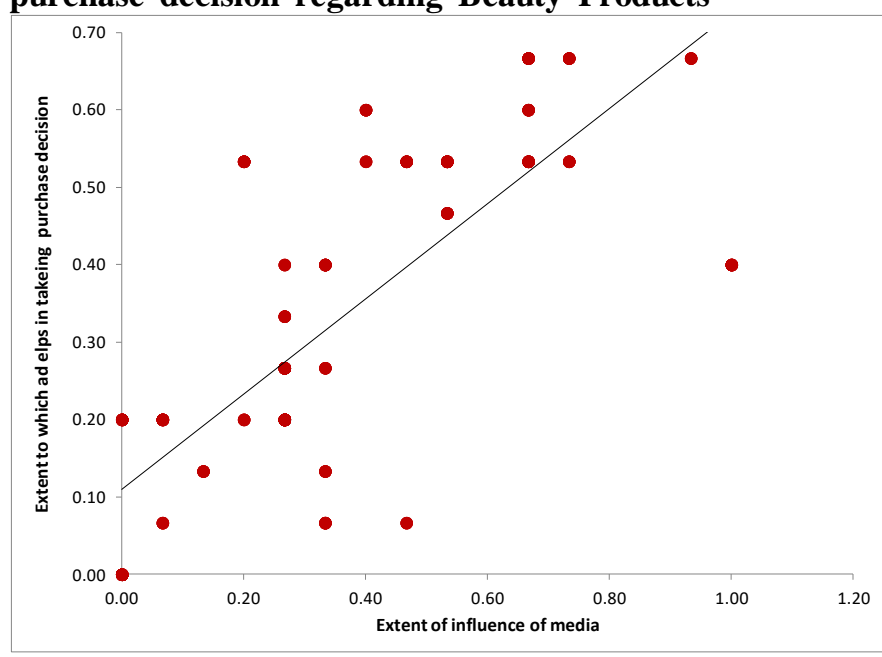

Table given above shows result of correlation coefficient test between different FMCG products rural population is using and to the extent to which they remember advertisement of any product. Test result shows highly significant correlation between use of different FMCG products and extent to which they remember advertisement of given product for all the products except tooth powder. The reason for this might be that from our other tables it is observed that rural people do not use branded tooth powder to high level hence non-significant correlation was found.

From the above results it can be concluded that advertisement has great influence on the purchase and use of branded products. If advertisement is good people will remember it long and which in turn will result in purchase of more branded products.

The above analysis is further done with categorizing different FMCG products in to four categories namely hygiene products, Beauty products, eatables and soft drinks.

Correlation between influence of media in making purchase decision regarding Eatables

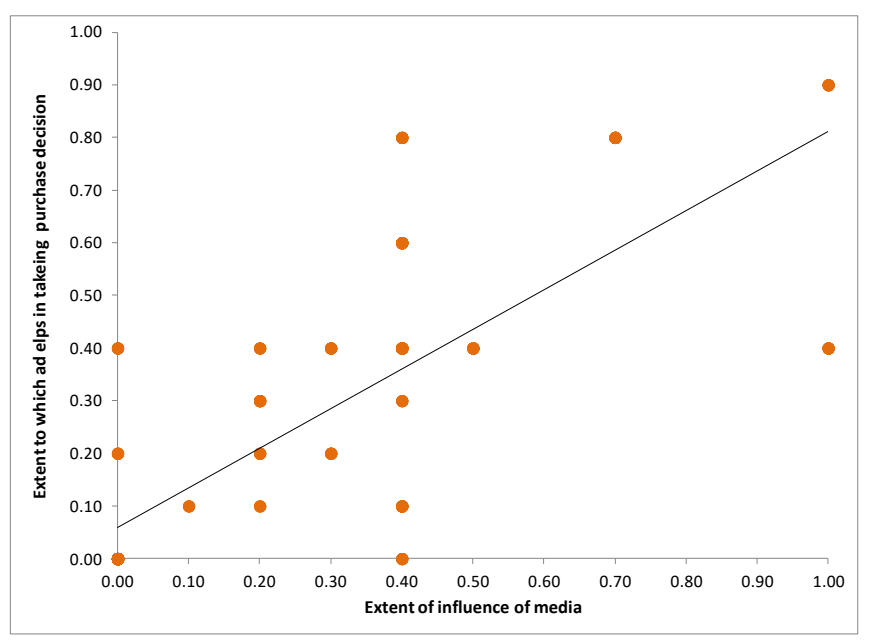

Correlation between influence of media in making purchase decision regarding Drinks

Coefficient of correlation results given below shows highly significant correlation between purchase of hygiene, beauty, eatables and soft drinks and extent of remembrance of advertisement of that category of product.

This proves our hypothesis that consumer decision making in rural areas for FMCG is influenced by magnitude of advertisement.

\section{FINDINGS AND RECOMMENDATIONS}

Following hypothesis test has been done in order to examine the data empirically-.

1) The modes of advertisement and user behaviour are associated.

2) Consumer decision making in rural areas for FMCG is influenced by the magnitude of advertisement.

Preference for Brand according to various demographic variables

A) According to age- 
- In case of washing soap, bathing soap and hair oil, majority is for local brands whereas in case of other fmcg products the accountability is somewhere different in reference to brand preference. In case of tooth paste and tooth powder the result is significant i.e. middle aged group go for brand preference. In case of face cream, bread, biscuit, coffee, milk ,soft drinks the result is again significant ie. Majority of people who are above 40 years go for brand preference. While for the rest fmcg products like talcum powder and tea.

The result interpreted is significant that lies between 30 and 40 years who have inclination towards brands.

B) According to gender-

- In case of interpreting brand preference for fmcg products according to gender, it can be interpreted from the above data that in case of tea, tooth powder and talcum powder, all male has a higher brand preference in comparison to female. While for the rest of the fmcg products the result got is non significant.

The result interpreted is non significant i.e. Consumers do not have a craving for branded products rather they all go for local brands irrespective of gender.

C) According to Marital Status-

- In case of interpreting brand preference for fmcg products according to marital status, it can be interpreted that in case of washing soap , bathing soap and hair oil , both married as well as unmarried accounts for local brands, and for the rest ie. Talcum powder, milk, coffee, tea, biscuits, bread, face cream, tooth paste and tooth powder, the result is non significant that means both married as well as unmarried use local brands. While in case of soft drinks, married people have a higher edge over unmarried ie they use branded soft drinks.

\section{D) According to Education-}

- In case of interpreting brand preference for fmcg products according to education, it can be interpreted that in case of bathing soap, washing soap and hair oil, both the categories i.e. educated or uneducated use local brands and for the rest i.e. milk, coffee, tea, soft drink, biscuits, bread, face cream, and tooth paste the result is non significant.While in case of tooth powder and talcum powder, the result is significant i.e. graduates and $\mathrm{sec} / \mathrm{sr}$. sec. groups use branded fmcg products respectively.

E) According to Occupation-
- From the above data, it can be interpreted that in case of milk, talcum powder, tea, tooth paste, tooth powder, majority of consumers those are into private jobs use brands. While in the case of coffee, soft drinks, biscuits, bread, face cream, the result is non significant. And for the rest categories, like hair oil, washing soap, bathing soap, all use local brands irrespective of occupation

F) According to Income-

- From the above data, it can be concluded that, consumers of income group up to $10000 /$ month use branded fmcg products like talcum powder, coffee and soft drinks. Other than this, consumers of income group between 10000-20000 / month use branded products like bread and tooth powder. In case of milk, tea, biscuits, face cream and tooth paste, the result is non significant. And for the rest such as bathing soap, washing soap, hair oil, all income groups use local brands.

G) Extent of use of media and helps of media in making decision to purchase FMCG product-

- Table shows correlation test results between use of different media and help of that media in making purchase decision about FMCG product. The results show highly significant correlation between extent of use of different media and help of that media in making purchase decision.

- For media like Internet, television, mobile and radio a highly significant correlation was found but it was very high for Internet, television, mobile and radio in the decreasing order of value of correlation and low for newspaper and magazine which is obvious because in rural areas people use newspaper and magazines very less as compared to other media like TV, radio etc. It is also observed that they are using internet at high extent because of the availability of internet on smart-phones hence internet in exerting great influence in making purchase decision about FMCG products.

- This proves our hypothesis that use of media has great influence in making purchase decision about FMCG products for rural population also.

H) Extent to which media has influence (remembrance) v/s making purchase decision of FMCG product with the help of media-

- Correlation coefficient test between different FMCG products rural population is using and to the extent to which they remember advertisement of any product. Test result shows highly 
significant correlation between use of different FMCG products and extent to which they remember advertisement of given product for all the products except tooth powder. The reason for this might be that from our other tables it is observed that rural people do not use branded tooth powder to high level hence non-significant correlation was found.

From the above results it can be concluded that advertisement has great influence on the purchase and use of branded products. If advertisement is good people will remember it long and which in turn will result in purchase of more branded products.

- The above analysis is further done with categorizing different FMCG products in to four categories namely hygiene products, Beauty products, eatables and soft drinks.

Coefficient of correlation results given below shows highly significant correlation between purchase of hygiene, beauty, eatables and soft drinks and extent of remembrance of advertisement of that category of product.

\section{REFERENCES}

[1] Awadhesh Kumar Singh (2005) Rural Marketing: Indian Perspective, 1st Edition

[2] Andras, T.L., and Srinivasan, S.S. (2003), Advertising Intensity and R\&D Intensity: Differences across Industries and Their Impact on Firm' $s$ Performance" , International Journal of Business and Economics, 2(2), 81-90.

\section{JOURNALS}

- International journal of management

- Indian journal of marketing

- Marketing Mastermind

- 4 Ps Business Marketing

- Marketing Management News

- Academy of Management journal

- Academy of Management review

- Bulletin of Economic Research

- Environmental Ethics

- Journal of Consumer Research

- Business World

- Journal of Business Studies

\section{INTERNET}

- http://zeenews.india.com/

http://www.adarmygroup.com/marketing-expert.php

- http://www.advertisingcrossing.com/article/

http://www.vsrdjournals.com/MBA/mbaindex.html 